\title{
Hva gjør pasientens tilgang til journalen med innholdet?
}

\author{
Pasientene kan nå selv lese sin egen journal hjemme på datamaskinen og følge utredning og diagnostisering \\ underveis i prosessen. Denne teknologiske muligheten er drevet frem av andre krefter enn legene. Hva vi \\ inkluderer i journalen og hvordan vi formulerer oss, er i endring. Uønskede effekter av endringene er i liten \\ grad blitt løftet frem.
}

Oslo universitetssykehus åpnet 1 . april 2016 for at pasienter kan lese journalnotater om seg selv på minjournal.no (1). Andre helseforetak har gjort det samme.

Pasientene har tidligere kunnet få tilgang til sin egen journal, men da alltid i ettertid, i papirformat og kun på forespørsel. Nå er tilgangen blitt både enklere og raskere, med muligheter for å følge pågående utredning og diagnostisering på egen datamaskin, nettbrett eller telefon. Polikliniske vurderinger med tentative diagnoser, radiologisvar og patologisvar kan studeres umiddelbart etter at legen har signert dem. På nettsiden opplyses det om at man kan lese «informasjon i journaldokumenter som behandler ikke har rukket å informere om» (1).

Prosjektmedarbeidere som tilrettelegger for pasienttilgang til journaler på internett informerer entusiastisk på avdelingsmøter på sykehuset om fordelene ved slike åpne journaler. Samtidig blir eventuelle innvendinger fra eldre klinikere avfeid. Vi blir oppfordret til å bruke folkelig språk, lage gode oppsummeringer og til å konkludere tydelig i journalnotater og epikriser for at pasienten selv og de pårørende skal kunne forstå innholdet. Som sykehusleger opplever vi at det ikke er lett - og kanskje heller ikke ønskelig - å konkludere bastant etter korte polikliniske konsultasjoner eller før pasienten er ferdig utredet.

\section{Hva skjer med innholdet i journalen?} Journalen har utviklet seg fra korte, håndskrevne legenotater til en mengde dokumenter forfattet av ulike typer helsepersonell, og den skal oppfylle mange krav (2). Vel vitende om at den også er et juridisk dokument, betrakter legene journalen først og fremst som et medisinsk dokumentasjonsog kommunikasjonsverktøy. I økende grad må vi forholde oss til en tredje funksjon: pasientinformasjon.

Vi bør spørre oss hva de ulike rollene og den økte og umiddelbare tilgjengeligheten av alt vi skriver i en hektisk arbeidsdag gjør med hvordan vi formulerer oss, med journalens innhold og dens kvalitet.

Kan det tenkes at visse typer informasjon blir utelatt? Det kan være viktig å dokumentere behandlerens oppfatninger av pasientens personlighetstrekk og grad av sykdomsinnsikt, særlig der dette kan påvirke både sykdomsforløp og prognose. Likeledes kan potensielt viktige opplysninger, som for eksempel mistanke om rusmiddelbruk, begynnende demens eller en påminnelse om å utelukke kreft, utelates av frykt for å skape sterke følelser hos leseren.

En annen konsekvens kan være at helsepersonell i sin streben etter å produsere feilfrie journalnotater - og av frykt for å unngå reaksjoner på det som skrives - unnlater a formidle klinisk refleksjon eller tvil. Spesielt gjelder dette for pasienter under utredning eller med uavklarte tilstander, som ofte møter yngre leger i spesialisering for den første vurderingen. En redsel for å skrive noe som helst som i etterkant kan tolkes som feilvurderinger, vil kunne true gode tentative diagnoser, differensialdiagnostiske overveielser og kliniske resonnementer i journalen. Da blir det tryggere utelukkende å rette oppmerksomheten mot objektive undersøkelser og negative funn i omstendelige journalnotater, gjerne fra en ferdiglaget mal. Etter at notatene er signert, vil de for all ettertid være korrekte og uangripelige.

Hvordan skal så usikkerheten, de kollegiale diskusjonene, de differensialdiagnostiske overveielsene og de vanskelige prognostiske tankene noteres? På en papirlapp som «dobbelt bokføring»? Dette er momenter som burde dokumenteres i sykehusjournalen, til pasientens beste. Å sette en diagnose har konsekvenser. Det kan oppleves som stigmatiserende for pasienten, men kan også utløse rettigheter. Overdreven forsiktighet hos leger ved journalskriving kan i verste fall føre til forsinkelse av endelig diagnose. Hvis vi økende grad ikke tør stole på den kliniske diagnosen, er vi redd for at omfanget av unødvendige supplerende undersøkelser vil øke.

Tradisjonelt har leger brukt epikriser og polikliniske notater til å gi positiv og negativ tilbakemelding til henviser om medisinske og praktiske anliggender som ikke direkte omhandler pasienten, for eksempel til å komme med konstruktiv kritikk om gode eller mangelfulle henvisninger. Resultatet kan bli at vi får flere informasjonskanaler mellom kolleger om kliniske opplysninger som omgår pasientjournalen. Forskningen omkring elektronisk tilgang for pasienter til journalen er mangelfull, og i flere studier understrekes det primært at pasientene finner dette positivt. Derimot er det ikke funnet at kvaliteten på innholdet er blitt bedre eller at de har gitt økt helsegevinst $(3,4)$.

\section{Legene må ta ansvar}

Samfunnets krav om åpenhet har forandret pasientjournalen. Har legene allerede tapt når det gjelder utformingen av profesjonens viktigste arbeidsverktøy? Har vi resignert overfor utviklingen? Er det akseptabelt dersom informasjon som er relevant for pasienter og kolleger samt diskusjon rundt vanskelige kliniske problemstillinger blir utelatt i den offisielle pasientjournalen?

Legene må våkne opp og ta pasientjournalens rolle, innhold og kvalitet opp til diskusjon. Ellers kan vi risikere at andre interessenter forandrer den til en intetsigende samling dokumenter av begrenset medisinsk nytteverdi.

\section{Jon Klokk Slettedal \\ jon.klokk.slettedal@gmail.com \\ Dag Fosmark}

Jon Klokk Slettedal (f. 1973) er overlege ved Oslo universitetssykehus og førsteamanuensis ved Universitetet i Oslo.

Forfatter har fylt ut ICMJE-skjemaet og oppgir ingen interessekonflikter.

Dag Sigurd Fosmark (f. 1959) er ph.d. og overlege ved Øyeavdelingen, Oslo universitetssykehus.

Forfatter har fylt ut ICMJE-skjemaet og oppgir følgende interessekonflikter: Han har mottatt honorar fra Bayer som medlem av firmaets rådgivningskomité.

\section{Litteratur}

1. MinJournal. https://www.minjournal.no/ (27.9.2016).

2. Janbu T. Hva skal en journal være? Tidsskr Nor Lægeforen 2006; 126: 2847.

3. Davis Giardina T, Menon S, Parrish DE et al. Patient access to medical records and healthcare outcomes: a systematic review. J Am Med Inform Assoc 2014; 21: $737-41$.

4. de Lusignan S, Mold F, Sheikh A et al. Patients' online access to their electronic health records and linked online services: a systematic interpretative review. BMJ Open 2014; 4: e006021.

Mottatt 19.9. 2016, første revisjon innsendt 2.10. 2016, godkjent 4.10. 2016. Redaktør: Ketil Slagstad. Engelsk oversettelse på www. tidsskriftet.no

Publisert først på nett. 